\title{
Effect of isodillapiole on the expression of the insecticide resistance genes GSTE7 and CYP6N12 in Aedes aegypti from central Amazonia
}

\author{
V.S. Lima ${ }^{1}$, A.C. Pinto ${ }^{2}$ and M.S. Rafael ${ }^{2}$ \\ ${ }^{1}$ Programa de Pós-Graduação em Genética, \\ Conservação e Biologia Evolutiva PPG GCBEv, \\ Instituto Nacional de Pesquisas da Amazônia, Manaus, AM, Brasil \\ ${ }^{2}$ Laboratório de Citogenética, \\ Genômica e Evolução de Mosquitos de Malária e Dengue, \\ Instituto Nacional de Pesquisa da Amazônia, Manaus, AM, Brasil \\ Corresponding author: M.S. Rafael \\ E-mail: msrafael@inpa.gov.br
}

Genet. Mol. Res. 14 (4): 16728-16735 (2015)

Received October 5, 2015

Accepted December 7, 2015

Published December 11, 2015

DOI http://dx.doi.org/10.4238/2015.December.11.20

ABSTRACT. The yellow fever mosquito Aedes (Stegomyia) aegypti is the main vector of dengue arbovirus and other arboviruses. Dengue prevention measures for the control of $A$. aegypti involve mainly the use of synthetic insecticides. The constant use of insecticides has caused resistance in this mosquito. Alternative studies on plant extracts and their products have been conducted with the aim of controlling the spread of the mosquito. Dillapiole is a compound found in essential oils of the plant Piper aduncum (Piperaceae) which has been effective as a biopesticide against $A$. aegypti. Isodillapiole is a semisynthetic substance obtained by the isomerization of dillapiole. In the present study, isodillapiole was evaluated for its potential to induce differential expression of insecticide resistance genes (GSTE7 and CYP6N12) in 3rd instar larvae of $A$. aegypti. These larvae were exposed to 
this compound at two concentrations (20 and $40 \mu \mathrm{g} / \mathrm{mL}$ ) for $4 \mathrm{~h}$ during four generations $\left(G_{1}, G_{2}, G_{3}\right.$, and $\left.G_{4}\right)$. Quantitative RT-PCR was used to assess the expression of GSTE7 and CYP6N12 genes. GSTE7 and CYP6N12 relative expression levels were higher at 20 than at $40 \mu \mathrm{g} / \mathrm{mL}$ and varied among generations. The decrease in GSTE7 and CYP6N12 expression levels at the highest isodillapiole concentration suggests that larvae may have suffered from metabolic stress, revealing a potential alternative product in the control of $A$. aegypti.

Key words: Aedes aegypti; Isodillapiole; qRT-PCR

\section{INTRODUCTION}

The yellow fever mosquito Aedes aegypti is one of the main vectors of dengue arboviruses, the Chikungunya virus and the Zika virus, among others. According to the World Health Organization (WHO), more than 50 million dengue cases are reported annually, especially in tropical and subtropical regions (Pinheiro and Chuit, 1998). In Brazil, the dengue virus was reintroduced in 1986 and has become since then a public health problem (Barbosa et al., 2015). In 2013, the country recorded more than 1.46 million cases of dengue according to the Pan American Health Organization (2013). Synthetic insecticides and organophosphates, such as pyrethroids and temephos, have been broadly used against the vector, preventing the spread of the dengue virus and other arboviruses. However, the intensive use of insecticides has caused resistance of the mosquito $A$. aegypti to many insecticides (Hemingway et al., 2004; Ranson et al., 2010). Alternative methods using extracts of plants of the family Piperaceae have shown effective control of Aedes larvae in Argentina, Bolivia, Peru, and Brazil (Bergeron et al., 1996; Chantraine and Shultes, 1998; Pohlit et al., 2004; Costa et al., 2005; Morais et al., 2007; Govindarajan, 2010; Pinto et al., 2012).

Piper aduncum is an aromatic plant from the family Piperaceae, which is found in the Amazon. It has a high content of essential oils (2.5 to $4 \%$ ) and is rich in dillapiole. Dillapiole is a phenyl ether that has already been successfully tested as a fungicide, molluscicide, acaricide, bactericide and, larvicide, with the advantage of being a biodegradable product (Silva, 2004). Rafael et al. (2008) found that dillapiole caused cytogenotoxic effects such as polynucleated cells, micronuclei and chromosomal breaks in neuroblasts and oocytes of larvae in four successive generations of $A$. aegypti. In addition, semisynthetic derivatives of dillapiole (1KL39-B and 1KL43-C) showed cytogenotoxicity in A. aegypti, evidenced by the increase in mean frequency of nuclear anomalies in neuroblasts and oocytes in four generations (Domingos et al., 2014). These authors found cumulative effect of anomalies, affecting the fertility of the adult form of this mosquito. Isodillapiole is a semisynthetic derivative of dillapiole obtained through the isomerization reaction (Figure 1). A study of this semisynthetic substance showed adulticidal activity against $A$. aegypti (Pinto et al., 2012).

Genes of the glutathione S-transferase (GST) family, including GSTE7, are associated with resistance to organochlorines (Lumjuan et al., 2011). GST genes belong to a superfamily of genes in prokaryotic and eukaryotic organisms and are involved in the detoxification of xenobiotics and endogenous compounds, intracellular transport, biosynthesis of hormones, and protection against oxidative stress (Enayati et al., 2005). Cytochrome P450 or monooxygenases (P450 or CYPs) are enzymes found in organisms from bacteria to mammals, and are responsible for the oxidative metabolism of endogenous and exogenous compounds (Scott and Wen, 2001). P450 is directly associated with resistance to pyrethroids in populations of $A$. aegypti (Bariami et al., 2012). 


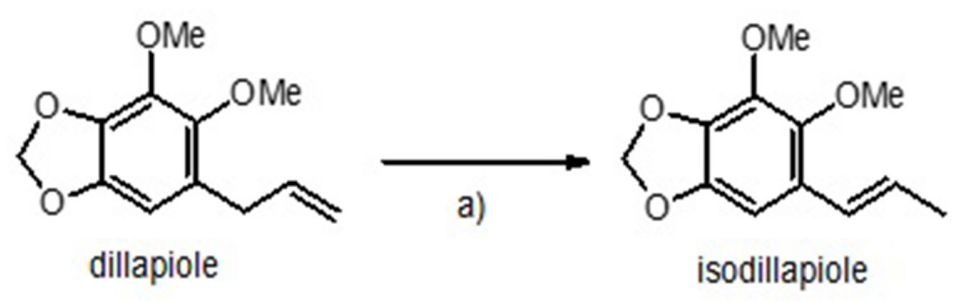

Figure 1. Synthesis of isodillapiole by the isomerization reaction (Pinto et al., 2012).

Quantitative real-time PCR (qRT-PCR) has been a useful tool in evaluating expression levels of insecticide resistance genes. Several studies using qRT-PCR have shown that genes of the GST and CYP families of Anopheles gambiae, Culex quinquefasciatus, and A. albopictus are super expressed, especially when induced by xenobiotic compounds (Edi et al., 2014; Hao et al., 2014; Liu et al., 2014). The genes GSTE7 and CYP6N12 have been linked to resistance to synthetic insecticides, such as DDT, temephos and pyrethroids (Lumjuan et al., 2011; Strode et al., 2012). In the present study, toxicological assays with 3rd instar larvae of $A$. aegypti from Central Amazonia were conducted using two concentrations of isodillapiole during four generations. To our knowledge, studies on the differential expression of insecticide resistance genes in $A$. aegypti using natural or semisynthetic compounds are scarce. Therefore, the relative expression levels of GSTE7 and CYP6N12 were quantified using qRT-PCR.

\section{MATERIAL AND METHODS}

\section{Collection of mosquitoes and experimental strains}

Larvae and pupae of $A$. aegypti were collected in the neighborhood of Cidade Nova (Manaus, Amazonas State, Brazil) (3॰1'21.36"S and 5958'5.32"W). Authorization for the use of animals in experiments was registered under the No. 2510890 (SISBIO, 2013). At the Laboratory of Cytogenetics, Genomics and Evolution of Mosquitoes (LCGEM) of the National Institute of Amazonian Research (INPA), mosquitoes were taxonomically identified with the keys of Consoli and Lourenço-de-Oliveira (1994). In the LCGEM insectarium, larvae and pupae were fed in plastic trays with commercial fish food (Tetra Cichlid). After the emergence of adult mosquitoes, males were fed with glucose solution (5\%) and females with hamster blood. Individuals were reared in standard insectarium conditions $\left(26^{\circ} \mathrm{C}, 70 \%\right.$ relative humidity, and $14 / 10 \mathrm{~h}$ light-dark cycle), to obtain strains reared under the same environmental conditions. These were used to produce subsequent generations $\left(G_{1}, G_{2}, G_{3}\right.$, and $\left.G_{4}\right)$ which were further tested in this study.

\section{Toxicological assay}

The toxicological assay using isodillapiole was performed with 3rd instar larvae of $A$. aegypti $(\mathrm{N}=200)$. Larvae were distributed in disposable plastic cups each containing 20 or $40 \mu \mathrm{g} / \mathrm{mL}$ isodillapiole diluted in $20 \mathrm{~mL}$ distilled water, during successive generations $\left(\mathrm{G}_{1}, \mathrm{G}_{2}, \mathrm{G}_{3}\right.$, and $\left.\mathrm{G}_{4}\right)$. Control larvae were treated with $5 \%$ DMSO. $\mathrm{G}_{1}$ larvae were exposed to isodillapiole for $4 \mathrm{~h}$, after with 20 larvae were randomly collected from each bioassay cup, frozen in liquid nitrogen, and kept at $-80^{\circ} \mathrm{C}$ 
for later extraction of total RNA. The remaining larvae continued to develop resulting in generation $\mathrm{G}_{2}$. The same procedure as used in generation $\mathrm{G} 1$ was used for generations $\mathrm{G}_{2}, \mathrm{G}_{3}$, and $\mathrm{G}_{4}$.

\section{Total RNA extraction and cDNA first strand synthesis}

Total RNA of 3rd instar larvae of $A$. aegypti was extracted with RNeasy Plant Mini kit (São Paulo, SP, Brazil), according to the manufacturer instructions. Concentration and quality of total RNA were determined in, respectively, a NanoDrop 2000 spectrophotometer from Thermo Scientific (Wilmington, DE, USA) and on a $1 \%$ agarose gel. RNA was treated with DNAse, using the Ambion Turbo DNA-free kit from Invitrogen (Carlsbad, CA, USA), to avoid contamination with genomic DNA. Complementary DNA (cDNA) first strand synthesis was carried out with the GoScript ${ }^{\mathrm{TM}}$ Reverse Transcription System kit from Promega (Madison, WI, USA), following the manufacturer protocol. The cDNA yield was $3.75 \mu \mathrm{g} / \mu \mathrm{L}$ for all samples.

\section{Real-time PCR}

The sequences of genes GSTE7 and CYP6N12 (IDs: AAEL007948 and AAEL009124, respectively), and RS7 (Telang et al., 2010) were obtained from GenBank. Primers for these genes were designed with the programs Gene Runner and Primer3 (Table 1). Quantitative RT-PCR was performed according to the protocol of Fast SYBR Green Master Mix (Applied Biosystems, Foster City, CA, USA), adapted for $A$. aegypti. Three reaction mixtures were made (in 1.5-mL microtubes), one for each primer set, containing $5 \mu \mathrm{L}$ SYBR Green Master Mix, $2 \mu \mathrm{L}$ Milli-Q water, $1 \mu \mathrm{L}$ forward and reverse primers $(2,0 \mu \mathrm{M})$, and $1 \mu \mathrm{L} \mathrm{cDNA}$, with a total volume of $10 \mu \mathrm{L}$. Next, samples were distributed on MicroAmp Optical 96-well microplates (Applied Biosystems) with 3 biological and 3 technical replicates, making a total of 9 plates. The injection of the samples in the plates was done using the Real-Time PCR System 7.500 (Applied Biosystems). Gene amplification conditions were as follows: initial denaturation at $95^{\circ} \mathrm{C}$ for $10 \mathrm{~min}$, and 40 cycles of $95^{\circ} \mathrm{C}$ for $15 \mathrm{~s}$ and $60^{\circ} \mathrm{C}$ for $60 \mathrm{~s}$.

Table 1. Sequences of oligonucleotides for real-time polymerase chain reaction (qRT-PCR).
\begin{tabular}{lllr}
\hline Primers & Gene & Accession No. & Amplicon (bp) \\
\hline Fw 5'-CGACAGCCATGCCATTCTCGTC-3' & GSTE7 & AAEL007948 \\
Rv 5'-TGATGCGAGCTTGGATGACGG-3' & CYP6N12 & AAEL009124 & 92 \\
Fw 5'-ACCGACGTGATTGCACCTGTG-3' & RS7 & AAEL009496 & 123 \\
Rv 5'-TGCCTTCAGGAACCGCCCATTG-3' & & & 118 \\
Fw 5'-TCAGTGTACAAGAAGCTGACCGGA-3' & & \\
Rv 5'-TTCCGCGCGCGCTCACTTATTAGATT-3' & &
\end{tabular}

$\mathrm{FW}=$ forward primer; $\mathrm{Rv}=$ reverse primer.

\section{Statistical analyses}

The relative expression levels of GSTE7 and CYP6N12 were determined using the comparative CT $(\triangle \Delta C T)$ method obtained with the formula $2^{-\Delta \Lambda C t}$, whereby $\mathrm{Ct}$ are the threshold values (Pfaffl, 2001). Relative expression levels were determined for each isodillapiole treatment (20 and $40 \mu \mathrm{g} / \mathrm{mL}$ ) in each generation $\left(G_{1}, G_{2}, G_{3}\right.$, and $G_{4}$ ) and technical triplicate, and compared with control samples. Quantitative RT-PCR results were normalized using the RS7 gene.

ANOVA and the Student's $t$-test were used to determine the $P$ value, whereby a $P \leq 0.05$ was considered significant. Statistical analysis were done with the software Statistica 12. 


\section{RESULTS}

First generation (G1) larvae of $A$. aegypti treated with 20 and $40 \mu \mathrm{g} / \mathrm{mL}$ isodillapiole during $4 \mathrm{~h}$ showed no significant mortality, ensuring subsequent generations $\left(G_{1}, G_{2}, G_{3}\right.$ and $\left.G_{4}\right)$. In the $\mathrm{G}_{2}$ generation, the relative expression of GSTE7 significantly increased $(P<0.05)$ in the $20 \mu \mathrm{g} / \mathrm{mL}$ isodillapiole treatment in relation to the control (Figure 2). The highest GSTE7 expression levels were observed in the $\mathrm{G} 2$ generation at the lowest isodillapiole concentration $(20 \mu \mathrm{g} / \mathrm{mL})$. However, in larvae treated with $40 \mu \mathrm{g} / \mathrm{mL}$ isodillapiole, gene expression levels in the different generations $\left(G_{1}, G_{2}, G_{3}\right.$, and $\left.G_{4}\right)$ were significantly lower compared to the control.

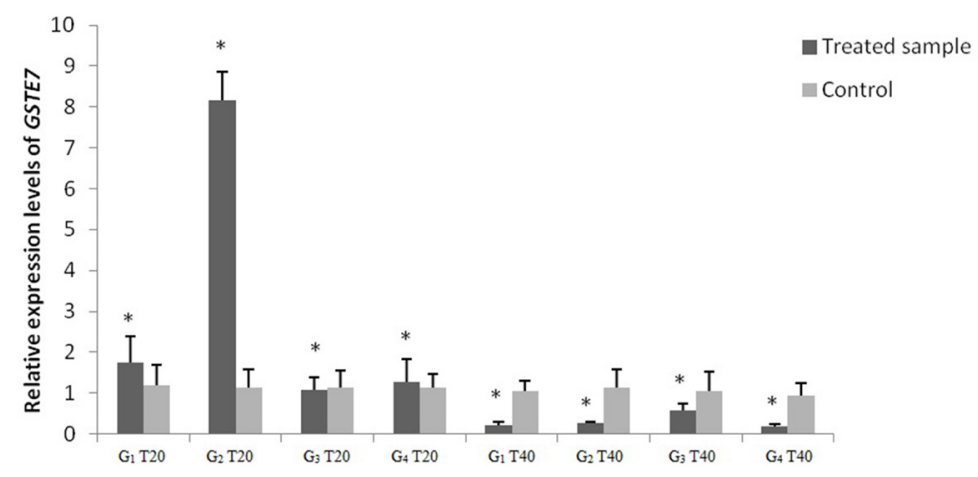

Figure 2. Relative expression of the GSTE7 gene in 3rd instar larvae of $A$. aegypti treated with isodillapiole at $20 \mu \mathrm{g} /$ $\mathrm{mL}(\mathrm{T} 20)$ and $40 \mu \mathrm{g} / \mathrm{mL}$ (T40). Different generations are represented by $\mathrm{G}_{1}, \mathrm{G}_{2}, \mathrm{G}_{3}$, and $\mathrm{G}_{4}$. ${ }^{*}$ Significant differences between control and treated samples $(P \leq 0.05)$; error bars are the standard deviation.

The expression of CYP6N12 in the different generations was significantly higher $(P<0.05)$ than in the controls in both treatments (20 and $40 \mu \mathrm{g} / \mathrm{mL}$ isodillapiole) (Figure 3). Gene expression levels were the highest in the $G_{2}$ generation treated with low isodillapiole concentration. At $40 \mu \mathrm{g} /$ $\mathrm{mL}$ isodillapiole, a decrease in larval expression levels was observed when compared to the lower concentration. The relative expression levels of CYP6N12 increased with every new generation $\left(G_{1}\right.$ $=3 X, G_{2}=9 X ; G_{3}=19 X$, and $G_{4}=22 X$ ).

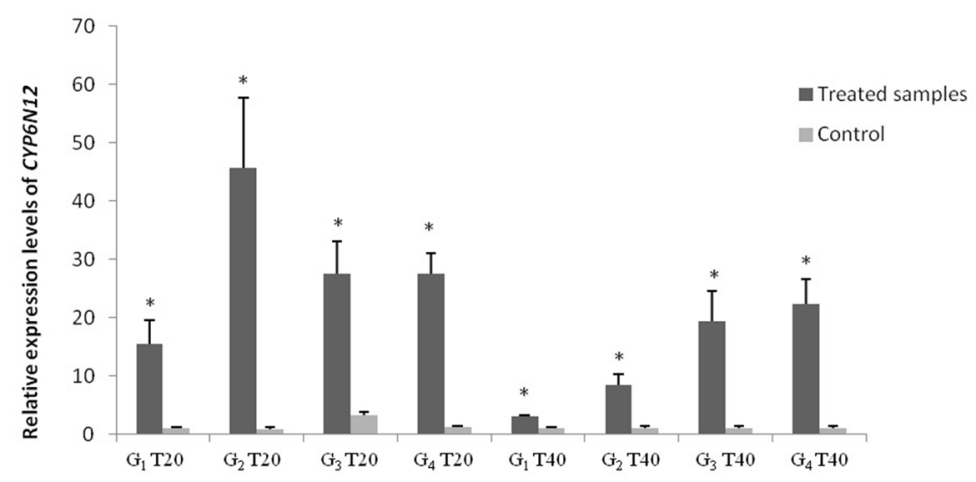

Figure 3. Relative expression of the CYP6N12 gene in 3rd instar larvae of $A$. aegypti treated with isodillapiole at 20 $\mu \mathrm{g} / \mathrm{mL}(\mathrm{T} 20)$ and $40 \mu \mathrm{g} / \mathrm{mL}$ (T40). Different generations are represented by $\mathrm{G}_{1}, \mathrm{G}_{2}, \mathrm{G}_{3}$, and $\mathrm{G}_{4}$. ${ }^{*}$ Significant differences between control and treated samples $(\mathrm{P} \leq 0.05)$; error bars are the standard deviation. 


\section{DISCUSSION}

The differential expression of various genes involved in the development of resistance to xenobiotics has been a useful tool in the search for alternatives for vector population control (Hemingway et al., 2004). The genes of the GST and P450 families are known to be related to the detoxification of xenobiotics in mosquitoes (Feyereisen, 2005; Zhu et al., 2008; Lumjuan et al., 2011).

Third instar larvae of $A$. aegypti exposed to two isodillapiole concentrations showed lower expression levels of GSTE7 and CYP6N12 at the higher isodillapiole concentration. The highest expression levels of both genes were observed in the $G_{2}$ generation exposed to the lowest isodillapiole concentration. The expression of GST epsilon class genes has been associated with cases of $A$. aegypti resistance in the presence of the synthetic insecticide DDT (Lumjuan et al., 2007). The resistance of $A$. aegypti is thought to be associated with CYP and GST activities in older generations (Rodriguez et al., 2002). This is not in line with our findings, which showed higher expression levels of GSTE7 in the $G_{1}$ and $G_{2}$ generations than in the $G_{3}$ and $G_{4}$ generations. At the highest isodillapiole concentration, expression levels of GSTE7 declined sharply compared to the control, suggesting that the toxicity of isodillapiole was higher at the highest concentration, causing a decrease in GSTE7 gene expression.

The analysis of CYP6N12 transcripts also revealed significantly higher expression levels at the lowest concentration of isodillapiole when compared to the control. Earlier studies have shown that the CYP6N12 gene shows higher expression levels after $6 \mathrm{~h}$ of exposure to sublethal concentrations of xenobiotic compounds such as copper sulfate, fluoranthene and permethrin (Poupardin et al., 2010). In addition, other genes of the CYP family have been associated with the metabolism of xenobiotic compounds (Poupardin et al., 2010). In the present study, isodillapiole increased gene expression levels within $4 \mathrm{~h}$, also at sublethal concentrations. This demonstrates that this compound causes increases gene expression levels of CYP6N12 in a short time interval. Moreover, the expression levels of both genes (GSTE7 and CYP6N12) at sublethal concentrations of isodillapiole decreased after the $G_{2}$ generation and stabilized in the $G_{3}$ and $G_{4}$ generations. Studies with 4th instar larvae of $A$. aegypti have demonstrated that the expression of insecticide resistance genes tends to decrease from generation to generation. This may be an evolutionary advantage to the insect, which is under selective pressure. Since the insecticide threat is reduced, gene expression levels decrease (Strode et al., 2012).

When the concentration of a particular xenobiotic compound is high, gene expression levels of the GST and CYP families tend to decrease. It was previously demonstrated that the exposure of $A$. aegypti larvae to high concentrations of toxic litter caused metabolic stress and significantly decreased the cytochrome P450 activity and the GST and CYP gene expression levels (David et al., 2006). This was also observed in A. aegypti exposed to isodillapiole, since the expression levels of GSTE7 and CYP6N12 were lower at a higher than at a lower isodillapiole concentration. The relationship between enzyme activity and gene expression levels of GSTs and CYPs was studied by Poupardin et al. (2008). These authors observed that the activity of GSTs and CYPs enzymes, and also the relative expression levels of GSTs and CYPs genes in larvae, increased after exposure to copper compounds, fluoranthene, and permithrin. In A. aegypti, isodillapiole at the highest concentration gradually increased expression levels of CYP6N12 over the four generations, suggesting that, from generation to generation, there was metabolic adaptation of $A$. aegypti larvae to this compound. Poupardin et al. (2012) observed that when 4th instar larvae of $A$. aegypti were exposed to lethal and sublethal concentrations of permithrin and fluoranthene, there 
was an increase in expression levels of CYP family genes after ten generations, which increased the resistance of larvae to these compounds. The pre-exposure of $A$. aegypti larvae to xenobiotic compounds can stimulate the increase in expressions levels of CYP6N12 which was observed here with isodillapiole.

Other derivatives of dillapiole (ethyl ether dillapiole and butyl ether dillapiole) were seen to be effective in causing mortality in eggs and larvae of $A$. aegypti, besides causing chromosomal abnormalities, micronuclei formation and polynucleated cells (Domingos et al., 2014). In this species, the toxicity of isodillapiole caused changes in the relative expression levels of GSTE7 and CYP6N12 genes. At the highest concentration, there was a significant decrease in GSTE7 expression levels, while the opposite was seen for CYP6N12. These results corroborate other studies on mosquitoes using other xenobiotic compounds. Results of the present study, on the toxic effects of isodillapiole in $A$. aegypti, indicate the need for further research on genes of the CYP6 and GSTE classes. Such studies will give more insight on the resistance of $A$. aegypti to synthetic insecticides and help controlling this primary vector, involved in the spread of several arboviruses around the world.

\section{Conflicts of interest}

The authors declare no conflict of interest.

\section{ACKNOWLEDGMENTS}

We are grateful to Fundação de Amparo à Pesquisa do Estado do Amazonas (FAPEAM) (Universal and PAPAC projects, \#1036/2011 and \#1570/2013, respectively), to the government of the State of Amapá and to Universidade Federal do Amapá (UNIFAP) for authorization to pursue a Master's course, and to CAPES/FAPEAM for granting a postgraduate scholarship. We are also grateful to Dr. Vera Maria Fonseca de Almeida e Val, Laboratório de Ecofisiologia e Evolução Molecular, INPA, for technical support. Dr. A. Leyva helped with English translation and editing of the manuscript.

\section{REFERENCES}

Barbosa JR, Barrado JCS, Zara ALS and Siqueira JBJ (2015). Avaliação da qualidade dos dados, valor preditivo positivo, oportunidade e representatividade do sistema de vigilância epidemiológica da dengue no Brasil, 2005 a 2009 . Epidemiol. Serv. Saúde 24: 49-58.

Bariami V, Jones MC, Poupardin R, Vontas J, et al. (2012). Gene amplification, ABC transporters and cytochrome P450s: unraveling the molecular basis of pyrethroid resistance in the dengue vector Aedes aegypti. PLoS Negl. Trop. Dis. 6: e1692.

Bergeron C, Marston A, Gauthier R and Hostettmann K (1996). Screening of plants used by North American Indians for antifungal, bactericidal, larvicidal, and molluscicidal activities. Pharm. Biol. 34: 233-242.

Chantraine JM and Shultes EL (1998). Insecticidal activity of essential oils on Aedes aegypti larvae. Phytother. Res. $12: 350-354$.

Consoli RAGB and Oliveira RL (1994). Principais mosquitos de importância sanitária no Brasil. Ed Fiocruz.

Costa JGM, Rodrigues FFG, Angélico EC, Silva MR, et al. (2005). Estudo químico-biológico dos óleos essenciais de Hyptis martiusii, Lippia sidoides e Syzigium aromaticum frente às larvas do Aedes aegypti. Braz. J. Pharmacog. 15: $304-309$.

David JP, Boyer S, Mesneau A, Ball A, et al. (2006). Involvement of cytochrome P450 monooxygenases in the response of mosquito larvae to dietary plant xenobiotics. Insect Biochem. Mol. Biol. 36: 410-420.

Domingos PRC, Pinto AC, Santos JMM and Rafael MS (2014). Insecticidal and genotoxic potential of two semi-synthetic derivatives of dillapiole for the control of Aedes (Stegomyia) aegypti (Diptera: Culicidae). Mutat. Res. 402518: 1-13.

Edi CV, Djogbenou L, Jenkins MA, Regna K, et al. (2014). CYP6 P450 enzymes and ACE-1 duplication produce extreme and 
multiple insecticide resistance in the malaria mosquito Anopheles gambiae. PLoS Genet. 10: 1-12.

Enayati AA, Ranso H and Hemingway J (2005). Insect glutathione transferases and insecticide resistance. Insect Mol. Biol. 14: 3-8.

Feyereisen R (2005). Insect cytochrome P450. In: Comprehensive molecular insect science (latrou K and Gill S, eds.). Vol. 4. Elsevier, Oxford, 1-77.

Govindarajan M (2010). Chemical composition and larvicidal activity of leaf essential oil from Clausena anisata (Willd.) Hook. f. ex Benth (Rutaceae) against three mosquito species. Asian Pac. J. Trop. Med. 3: 874-877.

Hao $\mathrm{CH}$, Wajidi MFF and Jaal Z (2014). Molecular cloning and xenobiotic induction of seven novel cytochrome P450 monooxygenases in Aedes albopictus. J. Insect Sci. 14: 163.

Hemingway J, Hawkes NJ, McCarroll L and Ranson H (2004). The molecular basis of insecticide resistance in mosquitoes. Insect Biochem. Mol. Biol. 34: 653-665.

Liu N, Li T, Reid WR, Yang T, et al. (2014). Multiple cytochrome P450 genes: their constitutive overexpression and permethrin induction in insecticide resistant mosquitoes, Culex quinquefasciatus. PLoS One 6: e23403.

Lumjuan N, Stevenson JB, Prapanthadara L, Somboon P, et al. (2007). The Aedes aegypti glutathione transferase family. Insect Biochem. Mol. Biol. 37: 1026-1035.

Lumjuan N, Rajatileka S, Changsom D, Wicheer J, et al. (2011). The role of the Aedes aegypti Epsilon glutathione transferases in conferring resistance to DDT and pyrethroid insecticides. Insect Biochem. Mol. Biol. 41: 203-209.

Morais SM, Facundo VA, Bertini LM, Cavalcanti ESB, et al. (2007). Chemical composition and larvicidal activity of essential oils from Piper species. Biochem. Syst. Ecol. 35: 670-675.

Pan American Health Organization (2013). Number of reported cases of dengue and severe dengue (SD) in the Americas, by country. Available at [http://www.paho.org/hq/index.php?option=com_topics\&view=rdmore \&cid=6290\&ltemid=407348la ng=en]. Accessed August 6, 2015.

Pfaffl MW (2001). A new mathematical model for relative quantification in real-time RT-PCR. Nucleic Acids Res. 29 : e45.

Pinheiro FP and Chuit R (1998). Emergence of dengue hemorrhagic fever in the Americas. Infect. Med. 15: $244-251$.

Pinto ACS, Nogueira KL, Chaves FCM, Silva LVS, et al. (2012). Adulticidal Activity of Dillapiol and Semi-synthetic Derivatives of Dillapiol against Aedes aegypti (L.) (Culicidae). J. Mosq. Res. 2: 1-7.

Pohlit AM, Quignard ELJ, Nunomura SM, Tadei WP, et al. (2004). Screening of plants found in the State of Amazonas, Brazil for larvicidal activity against Aedes aegypti larvae. Acta Amaz. 34: 97-105.

Poupardin R, Reynaud S, Strode C, Ranson H, et al. (2008). Cross-induction of detoxification genes by environmental xenobiotics and insecticides in the mosquito Aedes aegypti: impact on larval tolerance to chemical insecticides. Insect Biochem. Mol. Biol. 38: 540-551.

Poupardin R, Riaz MA, Vontas J, David JP, et al. (2010). Transcription profiling of eleven cytochrome P450s potentially involved in xenobiotic metabolism in the mosquito Aedes aegypti. Insect Mol. Biol. 19: 185-193.

Poupardin R, Riaz AM, Jones MC, Chandor-Proust A, et al. (2012). Do pollutants affect insecticide-driven gene selection in mosquitoes? Experimental evidence from transcriptomics. Aquat. Toxicol. 114-115: 49-57.

Rafael SM, Hereira-Rojas JW, Roper JJ, Nunomura SM, et al. (2008). Potential control of Aedes aegypti (Diptera: Culicidae) with Piper aduncum L. (Piperaceae) extracts demonstrated by chromosomal biomarkers and toxic effects on interphase nuclei. Genet. Mol. Res. 7: 772-781.

Ranson H, Burhani J, Lumjuan N and Black W (2010). Insecticide resistance in dengue vectors. Trop/KAnet J. 1.

Rodriguez MM, Bisset JA, Ruiz M and Soca A (2002). Cross-resistance to pyrethroid and organophosphorus insecticides induced by selection with temephos in Aedes aegypti (Diptera: Culicidae) from Cuba. J. Med. Entomol. 39: 882-888.

Scott JG and Wen Z (2001). Cytochromes P450 of insects: the tip of the iceberg. Pest Manag. Sci. 57: 958-967.

Silva MHL (2004). Tecnologias para o desenvolvimento agroindustrial de Piper aduncum L. Doctoral thesis, Universidade Federal Rural do Rio de Janeiro, Rio de Janeiro.

Strode C, Santos-MM, Magalhães T, Araujo A, et al. (2012). Expression profile of genes during resistance reversal in a temephos selected strain of the dengue vector, Aedes aegypti. PLoS One 7: 1-8.

Telang A, Peterson B, Frame L, Baker E, et al. (2010). Analysis of molecular markers for metamorphic competency and their response to starvation or feeding in the mosquito, Aedes aegypti (Diptera: Culicidae). J. Insect Physiol. 56: 1925-1934.

Zhu F, Feng J, Zhang L and Liu N (2008). Characterization of two novel cytochrome P450 genes in insecticide resistant house flies. Insect Mol. Biol. 20: 1365-1583. 